International Journal of Instruction e-ISSN: 1308-1470 • www.e-iji.net

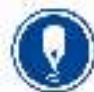

January $2021 \bullet$ Vol.14, No.1

p-ISSN: 1694-609X

pp. $827-846$

Article submission code

20200404032846

Received: 04/04/2020

Revision: 03/08/2020

Accepted: 25/08/2020

OnlineFirst: 28/11/2020

\title{
Flipped Learning, Self-Regulated Learning and Learning Retention of Students with Internal/External Locus of Control
}

\author{
Ensaf Nasser Al Mulhim \\ Dr., King Faisal University, Saudi Arabia, ealmulhim@kfu.edu.sa
}

|

This article investigates the effect of the flipped learning model on university students with internal/external locus of control regarding their self-regulated learning skills and learning retention in Saudi Arabia. The sample was divided into two groups according to learning style (internal/external locus of control). Both groups were taught through a flipped learning model. A self-regulated learning skills scale and a learning retention instrument were used. Results indicate significant differences between the experimental groups in favor of the internal locus control. The study highlights the necessity of identifying students' learning styles and finding the best e-learning environments and strategies that meet their learning preferences.

Keywords: learning style, flipped learning, self-regulated learning, learning retention, locus of control, higher education, student teacher

\section{INTRODUCTION}

Students learn in different styles. To make learning compatible and meaningful for individuals, the literature recommends personalizing the learning environment to meet different needs and characteristics (Chiang, 2016; Ismaeel \& Al Mulhim, 2019; Shahsavar \& Hoon, 2011; Tayebinik \& Puteh, 2013). Locus of control (internal/external) is a learning style that emphaizes students' beliefs that their success and failure is controllable and responsive (Rotter, 1966). Traditional teaching environments have been reported as less functional in meeting students' different learning styles (Uzunboylu \& Karagozlu, 2015).

Learning technologies play a key role in meeting various learning styles (Uzunboylu \& Karagozlu, 2015). Flipped learning, a blended learning strategy, heavily depends on learning technology in its support of student-centered learning. In such a learning environment, students learn the lecture's content at home using computer-mediated objects (Chen, Liou, \& Chen, 2019). Students can actively control their learning experience to achieve their individual learning goals. This learning environment encourages students' active and self-directed learning.

Recently, popular e-learning environments have engaged learners in learning construction, which amplifies collaborative, self-directed, and self-regulated learning

Citation: Al Mulhim, E. N. (2021). Flipped Learning, Self-Regulated Learning and Learning Retention of Students with Internal/External Locus of Control. International Journal of Instruction, 14(1), 827846. https://doi.org/10.29333/iji.2021.14150a 
(Kang, 2015). Self-regulated learning refers to a student's ability to understand, control and manage their learning environment (Schraw, Kauffman \& Lehman, 2002). The literature shows that self-regulated learners are more successful learners in these environments (Barak, 2009; Sun, Wu, \& Lee, 2017). Educators must develop skills with e-learning strategies to support students' use of self-regulated learning skills. Students employ self-regulated learning skills to prepare for face-to-face activities and discussions. Instructors can use traditional class time to encourage active and valuable student participation rather than the passive receipt of information. Thus, flipped learning characteristics may help learners be better self-regulated learners. Moreover, active learning environments allows students to actively engage in their learning tasks, affecting knowledge construction, and learning retention (Hawks, 2014; Kerr, 2015; Mithun \& Evans, 2018; Shatto, L'Ecuyer, \& Quinn; 2017). This paper explores how the flipped learning model affects self-regulated learning and learning retention of students with internal/external locus of control at King Faisal University, Saudi Arabia.

\section{LITERATURE REVIEW}

\section{Flipped Learning}

The flipped learning instructional model inverts the traditional classroom. The traditional lecture content becomes student homework in the form of videos, presentations, screencasts, or vodcasts. Activities that traditionally constitute at-home assignments become in-class activities (Baytiyeh, 2017). Flipping saves time that was consumed by the introduction of a new concept for more valuable student engagement in collaborative activities (Milman, 2014). In the flipped classroom, a teacher is a knowledge facilitator rather than a knowledge deliverer. Therefore, students are empowered to take control of their learning process (Lai \& Hwang, 2016).

Flipped learning is based on student-centered learning theories (Akçayır \& Akçayır, 2018; Baytiyeh, 2017). The self-directed learning theory is a student-centered learning theory that supports flipped learning (Sletten, 2017). The theory has two components (see Figure 1):

1. Out-of-Classroom: Students prepare for in-class activities with self-regulated learning skills. Students study learning resources and take notes on what they have learned.

2. In-Classroom Activities: Students participate in discussions on the content of the learning resources, and apply the content to their assignments to demonstrate deeper understanding.

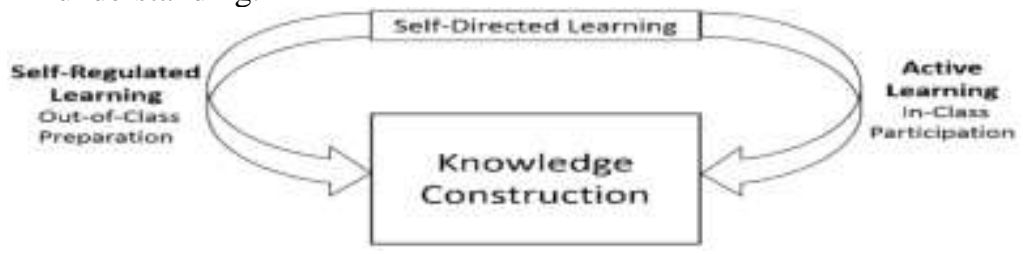

Figure 1

Components of self-directed learning theory (Sletten, 2017) 
Research reports several ways in which the flipped classroom model makes the learning and teaching process more effective. The flipped model frees class time, which provides more opportunities for meaningful in-class activities like role-play, debates, problembased learning, and peer-assisted learning. The literature reveals that flipped learning can improve students' learning outcomes. Milman (2014) and Shyr et al. (2018) agree that flipped classroom provides more time for more engaging instruction, especially when teaching in a hybrid or blended settings. Shyr et al. (2018), moreover, believe that a variety of in-class and out-of-class activities can influence to improve students' academic achievement and attitude toward learning and encourage them to become active learners. Moreover, Akçayır and Akçayır (2018) conduct a large-scale review of the literature seeking the advantages and challenges of the flipped classroom approach. They found that the most frequently reported advantage is that a flipped classroom could improve students' learning performance. O'Flaherty and Phillips (2015) review of the literature also reveals evidence on the positive influence of flipped learning on improving academic performance and student and staff satisfaction. Baytiyeh's (2017) study shows that in addition to improving students' performance, flipped classrooms could help to improve their self-regulated learning skills. Abeysekera and Dawson (2015) also suggest that a flipped classroom could improve student motivation. The findings from a study carried out by Chao et al. (2014) assert the effectiveness of the flipped learning approach in terms of students' achievements, learning attitudes, motivation, and self-evaluation.

The literature notes challenges to flipped learning. It is found that the flipped classroom is time consuming due to the redesign of the course. Time-consuming activities include recording video lectures, creating presentations, developing meaningful in-class activities, etc. In addition, the students' at-home learning content may be insufficiently produced or has technical problems. This learning model is very student-centered as it relies on students watching the learning materials at home. Completion of the at-home assignment is not guaranteed. Poor preparation for in-class activities may reduce or eliminate a student's engagement. In addition, some students may not be able to learn through a computer, and/or may require scaffolding (Akçayır \& Akçayır, 2018; Milman, 2014; Shyr \& Chen, 2018).

Several studies cite the effectiveness of the flipped learning model on students' learning outcomes. Considering students' various learning styles, the present study investigates the influence of the flipped learning model on students with different locus of control related to self-regulated learning and learning retention.

\section{Locus of Control}

The literature has cited learning styles as key predictors on how a student may learn and interact in the learning environment (Ismaeel \& Al Mulhim, 2019). This understanding of how learning is achieved could help teachers design more appropriate learning environments for their students according to their learning styles. Locus of control is a learning style defined as a generalized individual's belief about how responsive and controllable the environment is based on situations and experiences (Rotter, 1966). 
The two types of locus of control are external and internal. People with external locus of control believe that events and outcomes are caused by external factors like chance, fate, or the actions of others. In contrast, internal locus of control attributes events and outcomes to behaviors or actions (Rotter, 1966).

The literature suggests that learning technologies could address different learning styles by providing facilities for students' learning that are not possible with other media. Uzunboylu and Karagozlu (2015) argue that flipped learning could address different learning styles, whereas traditional learning depends on the instructor's teaching styles.

Locus of control is based on Rotter's (1954) social learning theory. Here, reinforcement is important in increasing expectations that a behavior or event will be influenced by its reinforcement in the future. In contrary, the reinforcement will reduce or extinguish the expectancy of that reinforcement once an expectancy for such a behavior or event is a failure. Internally controlled individuals are more motivated by their achievement and goals than outer guidance. On the other hand, externally controlled individuals have less or no control over their achievement and look for causes of their failure (Bajwa, Batool, Azam, \& Ali, 2016).

Significant research has considered students' learning styles such as ambiguity tolerance (Chiang, 2016; Ismaeel \& Al Mulhim, 2019; Tayebinik \& Puteh, 2013), field independence (Chen et al., 2019; Onyekuru, 2015; Wang, 2014), locus of control (Hsia, Chang, \& Tseng, 2014; Joo, Joung, \& Sim, 2011; Severino, Aiello, Cascio, Ficarra, \& Messina, 2011), and learning outcomes in learning environment. Many studies emphasize the influence of locus of control on learning outcomes. However, the results of these studies conflict. Some report that locus of control impacts attitudes, performance, achievement, satisfaction, motivation, and success in favor of internally controlled students. For example, Bajwa et al. (2016) find that locus of control could influence distance learning students' satisfaction. Similarly, Joo, Lim and Kim's (2013) examination of the predictors of learning outcome in an online university context, reveal that students' locus of control is one of the significant predictor of their satisfactions. Hsia et al. (2014) conduct a study to investigate the impact of locus of control on elearning trainees and their acceptance of technology. The results assert that locus of control had significant and direct influence on perceived usefulness and perceived ease of use. In another exploration, Hsia (2016) found that locus of control has a strong effect on students' beliefs (perceived usefulness, perceived ease of use, and perceived behavioral control) toward m-learning. Nakayama, Leh, \& Santiago (2015) explore the relationships among the instructional design of flipped classrooms using social media, students' experience, and students' characteristics including locus of control. The results assert that there is a strong relationship between students' characteristics (i.e. locus of control) and instructional design of flipped classrooms that uses social media in terms of students' activity in favor of the internally controlled students. In contrast, some studies report no differences between internally or externally controlled students in terms of learning outcomes (Cox, 2012; Gökçearslan \& Alper, 2015; Kelly, 2012). 
Although locus of control is a learning style that has been closely examined in e-learning contexts with various variables, it has been slightly tested in flipped learning environments. This requires more investigation.

\section{Self-regulated learning skills}

The increasing demand of online learning environments requires learners to be more independent and self-directed as they autonomously and actively engage in the learning process (Serdyukov \& Hill, 2013; Wang, Shannon, \& Ross, 2013). Contrary to traditional learning environments, learners in online environments need the selfgenerated ability to control, manage, and plan their learning actions using self-regulated learning skills. Self-regulated learning is an individual's ability to understand and control the learning environment. Zimmerman (1989) indicated that self-regulated learners plan, set goals, organize, self-monitor, and self-evaluate their learning rather than depend on teachers.

The theory of self-regulated learning identifies three processes of self-regulation: (1) behavioral monitoring; (2) self-evaluation; and (3) self-reaction (Bandura, 1986). These cognitive skills are crucial for individuals to determine personal goals (Garcia, Falkner, \& Vivian, 2018). The process of self-regulation involves four stages: (1) task definition; (2) goal setting and planning; (3) enactment; and (4) adaptation. These stages occur in a microcognitive system of five processes: (1) conditions; (2) operations; (3) products; (4) evaluation; and (5) standards.

Nine self-regulation strategies were identified by Zimmerman (1989). Magno (2010) developed seven strategies to self-regulation learning: (1) memory strategy; (2) goal setting; (3) self-evaluation; (4) seeking assistance; (5) environmental structuring; (6) learning responsibility; and (7) organizing. These factors were intercorrelated as strong indicators of academic regulation learning.

Many studies agree that self-regulated learning positively affects outcomes like academic performance, achievement, and success. Broadbent (2017) investigates the online and blended students' use of self-regulated learning strategies in a higher education context. She found that students use self-regulated learning strategies equivalent in both online and blended settings. She also highlights that self-regulated learning strategies could improve students' academic performance. Additionally, Broadbent and Poon (2015) reviewed several studies that explore the use of selfregulated learning strategies in the online higher education context. They found that selfregulated learning strategies are positively correlated to students' academic success, highlighting the strategies of time management, metacognition, critical thinking, and effort regulation in particular. Another study was conducted by Lai and Hwang (2016) to compare between a self-regulating flipped classroom and conventional flipped classroom in an elementary school mathematics course in terms of academic achievement, self-regulated learning skills, and self-efficacy. One result of their study showed that students with higher self-regulated learning skills had significantly better academic achievement. Moreover, Littlejohn, Hood, Milligan, and Mustain (2016) studied the effect of self-regulated learning on the behaviour and the employment of 
self-regulated learning skills of students who enroll in a MOOC. Their study identified differences in behaviour associated with five self-regulated learning sub-processes including motivation and goals setting, self-efficacy, task interest value, task strategies, and self-satisfaction and evaluation, in favour of the students with higher self-regulated learning.

Self-regulated learning skills are based on classroom opportunities where students control their pace and design of learning. In this setting, students are responsible for their learning. This view, which suits the flipped learning model, encourages students to be self-driven as they complete tasks outside of the classroom in order to be prepared for in-class activities. To achieve this, students should be able to set personal goals and deploy effective learning strategies (Peng, 2012). Additionally, students should be able to monitor their learning behaviors (for example, knowing how to regulate their time and resources), as well as other appropriate strategies aimed at achieving their learning goals. Students with higher self-regulation levels are more effective in their learning, and are more successful in a flipped learning setting than those with low self-regulation levels (Winne, 2013).

The literature has cited several findings related to the impact of flipped learning on improving students' self-regulated learning. Some studies reported no significant evidence showing that flipped learning correlates to students' self-regulated learning skills (Elakovich, 2018; Sun et al., 2017; Wang \& Zhu, 2019). On the other hand, some studies asserted that flipped learning positively correlates to self-regulated learning skills. For example, Sletten's (2015) study finds a significant correlation between students' self-regulated learning skills and flipped classroom perceptions. It also suggests that self-regulated learning skills and flipped course perceptions were predictors of achievement. The study by $\mathrm{Ng}$ (2018) examines the effectiveness of flipped classroom pedagogy, concerning self-regulation skills, to enhance formative learning outcomes for first-year university students. The study suggests that flipped classroom pedagogy was effective enabling students to achieve all self-regulated learning skills. Alten, Phielix, Janssen, and Kester (2020) investigate the effects of selfregulated learning skills support included in the pre-class (home) activities in a flipped classroom setting on students' self-regulated learning skills and learning outcomes. Their findings involve evidence of the role of flipped learning in stimulating students to perform self-regulated learning skills. Jovanović, Gašević, Dawson, Pardo, and Mirriahi (2017) suggest that the success of students in flipped learning settings depends on the extent to which the students use of self-regulated learning skills. Students with low selfregulated learning skills would need more help and scaffold from the instructors to develop their skills and consequently achieve their goals. The flipped learning settings can provide such scaffold and help to develop these skills through undertaking and completing well-defined and structured preparatory activities. Similarly, the study of Sun, Xie, and Anderman (2018) recommended that it is essential to make flipped classrooms effective for academic achievement. For higher achievement, flipped classrooms should enact appropriate strategies in order to support learners in enhancing self-regulation. 
It is important to determine the best learning strategies and environments that suit students with different learning styles. In doing so, students can develop self-regulating learning skills for learning competencies crucial in the $21^{\text {st }}$ century. However, the literature lacks information on learning styles and self-regulated learning. Therefore, the current study investigates the effect of flipped learning on self-regulated learning of students with different locus of control (internal/external).

\section{Learning Retention}

Learning retention focuses on the transfer of new information from short-term to longterm memory (Andriotis, 2017). This type of knowledge, which remains in an individual's mind, is one of the most important academic outcomes. The active learning environment is an important factor in students' academic outcomes, including learning retention (Mithun \& Evans, 2018). Several studies have reported that flipped learning effectively enhances students' learning retention. Estes, Ingram, and Liu (2014) state that flipped learning is a unique approach to improve learner retention and using class time wisely. Similarly, Hawks (2014) confirms that the flipped learning approach can enhance learning retention through rich pre- and in-class interactive exercises and encourage in-depth learning facilitated by students' aptitude and passion. In her analysis of 24 research studies on the influence of flipped learning on several learning outcomes in the field of engineering education, Kerr (2015) found only one study that explores learning retention. That study reports a vast improvement in students' learning retention because of the flipped learning intervention. Shatto et al. (2017) evaluate a flipped learning approach for accelerated second-degree nursing students during their primary medical-surgical nursing course, compared to a traditional teaching method. Following the course, learning short-term retention (3 months later) and long-term retention (12 months later) were measured. The findings revealed flipped classroom helps to promote both short- and long-term retention. The study, more specifically, indicates that shortterm retention was greater, and long- term retention was significantly great in favour of the students who were taught using a flipped learning approach. Mithun and Evans (2018) carried out a study of a flipped classroom teaching approach compared to a traditional lecture-based teaching approach in an introductory programming course in terms of students' learning outcomes. The study concludes that the class grade average in flipped sections increased compared to traditional sections, had a positive impact on students' learning, motivation, engagement, and retention.

The following studies examined the influence of locus of control on students' learning outcomes such as students' satisfaction (Bajwa et al., 2016; Joo et al., 2013), students' sense of community and academic success (Gökçearslan \& Alper, 2015), technology acceptance (Hsia, 2016; Hsia et al., 2014), students' activity (Nakayama et al., 2015). However, there is a lack in the literature that examines the effect of students' locus of control on learning retention and more studies are needed. This confirms the need for the present study. 


\section{Research Questions and Hypotheses}

The current research investigates the impact of the flipped learning strategy on selfregulated learning skills and learning retention of students with internal/external locus of control. The research asks the following questions:

- Does the flipped learning strategy affect self-regulated learning skills of students with internal/external locus of control?

- Does the flipped learning strategy affect the learning retention of students with internal/external locus of control?

To answer these questions, the following hypotheses will be examined:

- There are no statistically significant differences at the level of $(0.05)$ between the average scores of the self-regulated learning skills scale of students with internal/external locus of control due to employing the flipped learning strategy.

- There are no statistically significant differences at the level of $(0.05)$ between the average scores of the learning retention of students with internal/external locus of control due to employing the flipped learning strategy.

\section{METHOD}

This study uses the experimental research approach to determine the influence of the flipped learning strategy on students' self-regulated learning skills and the learning retention of students with internal/external locus of control.

\section{Participants}

Sixty students participated in the study. The students were enrolled in the diploma of education course, "Computer Applications in Education," in the Faculty of Education at King Faisal University. The research was conducted during the second semester of the 2017-2018 academic school year. Participants were classified either internal or external locus of control. Each experimental group had 30 students.

\section{Research Design}

The study employed Branch's (2009) analysis, design, development, implementation, and evaluation (ADDIE) model for instructional design in constructing the experimental treatments, and utilized the model's five procedural steps.

Analysis: This stage:

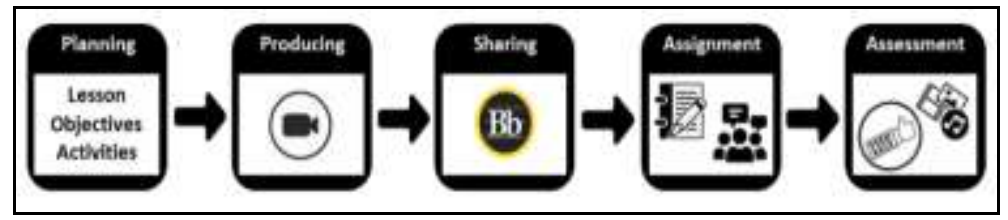

Figure 2

Flipped learning framework 
- identifies the overall goal of the research by investigating the impact of the flipped learning strategy on self-regulated learning skills and learning retention of students with internal/external locus of control.

- identifies the learners' characteristics by selecting postgraduate students in the College of Education's "Computer Applications in Education" (approximately the same educational level and age [23-30 years], unfamiliar with the educational content in "Designing Digital Learning Objects," and possessing basic skills for dealing with computers and the Internet).

- analyzes learning tasks and needs by selecting assignments titled "Designing Infographic Using Adobe Photoshop" and "Creating Animation Using Animaker and Powtoon." These were then broken into smaller tasks.

- analyzes the learning environment by applying the experiment in computer labs connected to the Internet.

Design: In setting up the experimental treatment of the study, a framework was designed based on the flipped learning literature. See Figure 2 (Cab1, 2018; Song \& Kapur, 2017; Tune, Sturek, \& Basile, 2013).

This framework has the following steps:

1. Planning: we selected the "Designing Digital Learning Objects" flipped lesson. The lesson's objectives were determined. Activity plans included "Designing Infographic Using Adobe Photoshop" and "Creating Animation Using Animaker and Powtoon."

2. Producing: Here we create an introductory presentation on the infographic design. Some video clips were recorded to demonstrate the use of Adobe Photoshop, Animaker, and Powtoon.

3. Sharing: Learning resources were available to students through Blackboard. Other instructions included the use of resources.

4. Assignment: Students were required to watch the videos and other resources. They prepared for in-class activities by taking lesson notes. In the class, the teacher discussed the resources and answered students' questions. Students of each experimental group were divided into subgroups. Tasks were assigned to the subgroups. Task topics included:

- Internet: Definition, advantages, disadvantages, Internet protocols, Internet services, and applications in education

- Web 2.0: Definition, characteristics, comparison between Web 1.0 and Web 2.0, Web 2.0 technologies, and services in the education field

5. Assessment: Groups presented their work to the class and received feedback from the teacher and other groups.

\section{Development}

- Media elements (i.e., presentations, video clips) were produced to discuss the objectives of the flipped classroom model. 
- Media was available to students on Blackboard. Tasks were set and explained in the assignment section. A group discussion board was created.

Implementation: This stage involved a pilot study on a sample of 10 randomly selected students in the College of Education, King Faisal University who were different from the main experiment sample. Participants' characteristics mirrored the study sample. Rotter's scale of locus of control was applied to the pilot sample and students were divided into two groups (five students each) according to their internal or external locus of control. The experimental treatment (flipped classroom) was conducted to ascertain clarity, check its suitability to the students' level, calculate reliability and validity of the measuring instrument, and identify potential difficulties encountered during the implementation of the actual experiment. Magno's (2010) scale of self-regulated learning was administered after the treatment. An achievement multiple-choice test was prepared and applied two weeks after the experimental treatment ended. Also, the timeframe for implementing the main experiment was considered.

Evaluation: The evaluation involved the formative evaluation of all stages of the experiment, including designing, producing, and testing treatments. This ensured the integrity of the previous stages and assessed their validity. It considered feedback from the pilot experiment. The result of the formative evaluation was used to make necessary amendments to the treatments.

\section{Instruments}

\section{Locus of control scale}

The researcher administered the Rotter (1966) locus of control scale to classify the study sample according to this learning style. The scale aimed to identify students in which perceived reinforcement was contingent on their behavior as compared to chance or experimenter control. The scale consisted of 29 forced-choice items (including six filler items) of two statements. Each reflected a mixture of external and internal control. One score was given for the external control statement; a zero was given for the internal control statement. This means that the highest score gained was 23 . A score less than 12 reflected internal locus of control; greater than 12 reflected external locus of control.

Rotter (1966) reported scale reliability of 0.79 by test-retest, a satisfactory value indicating high reliability. Similarly, the present study calculated the reliability by testretest, reflecting a score of 0.81 as a high reliable value.

\section{Self-regulated learning skills scale}

The academic self-regulation learning scale was employed to identify the level of students' self-regulated learning skills (Magno, 2010). The scale, in its final form, consisted of 55 items divided into seven factors.

In the memory strategy, 14 items represented students' efforts to memorize the learning materials, either overtly or covertly (i.e., notecards, summaries, lists).

1. Goal Setting: Five items identified educational goals and sub-goals. It made plans for sequencing, timing, and roles and activities to be implemented for the achievement of these goals using scheduled planning. 
2. Self-Evaluation: Twelve items indicated students' observations of performance. This ensured the quality or progress of their work to achieve a certain outcome (monitoring improvement and seeking peer feedback).

3. Seeking Assistance: These eight items were used to complete learning tasks. They included the learner seeking help from teachers, peers, or other learning sources (i.e., research, books, Internet).

4. Environmental Structuring. Five items described how a student arranges the learning setting to improve their learning (avoiding television and noisy places).

5. Learning Responsibility: Five items indicated students' efforts to accomplish and submit their assignments on time and without delay.

6. Organizing: Six items included the rearrangement of learning materials and information (physical area to improve learning).

Magno's instrument used a 4-point Likert scale (strongly agree $=4$, agree $=3$, disagree $=2$, strongly disagree $=1$ ). The maximum score a learner could obtain on the scale was 220. The lowest score was 55. Some amendments were made while drafting the scale items to suit the nature of the current study. The validity of the amended scale was calculated by presenting it to a group of judges in the field of educational psychology. They surveyed the appropriateness of the wording and suitability of the scale items for the general purpose of the scale. The judges recommended minor changes to some items. Changes were made and finalized.

Magno (2010) indicated the reliability of the scale's factors by calculating Cronbach's alpha coefficients as 0.82 for Memory strategy, 0.87 for Goal setting, 0.83 for Selfevaluation, 0.74 for Seeking assistance, 0.73 for Environmental structuring, 0.75 for Learning responsibility, and 0.78 for Organizing.

The author of the present study calculated the reliability of the scale using Spearman's coefficient by applying it to a pilot sample. It was found that the scale is 0.79 reliable in total, which is a high result indicating the high reliability of the scale.

\section{Learning retention instrument}

A multiple-choice test of 30 items was prepared to measure the learning retention of the two experimental groups on concepts related to the Internet and Web 2.0. Each test item was allowed one point of the total score. The total score on the test was 30 points. To find the validity of the achievement test, items were initially reviewed by a group of judges in the field of educational technology. They reviewed its coverage of the educational goals, its relevance to the content, and the relevance and precision of the test items. The judges unanimously agreed to grant the test more than $97 \%$. Accordingly, some item wording was amended. The test became applicable for the participants of the pilot experiment to calculate the statistical validity of the test.

The pilot group of 10 students took the test two weeks after the pilot experiment. Reliability was calculated using the split-half method, as well as the Spearman-Brown equation and correlation coefficient between the two parts. The reliability coefficient 
(0.88) was an acceptable value for exam reliability. The average response time for the test was 33 minutes.

\section{Experimental Procedure and Data Collection}

1. The locus of control scale by Rotter (1966) was administered to all the 60 participants who enrolled in the Diploma program of education course entitled "Computer Applications in Education," in the Faculty of Education at King Faisal University to classify as either internal and external. There was 30 students' internal locus of control and 30 students' external locus of control. Then both groups (internal and external) were re-divided randomly into six sub-groups each with five students per group to simplify the group work and cooperation.

2. The achievement pre-test was applied to all the experimental groups (internal and external) to ascertain that the equivalence of the two groups and to ensure that they did not know the scientific content in advance.

3. An introductory meeting was held to explain the flipped classroom, its objectives, and how it works. The task of "create a learning object" was assigned to all the groups. Task topics included:

- Internet: Definition, advantages, disadvantages, Internet protocols, Internet services, and applications in education

- Web 2.0: Definition, characteristics, comparison between Web 1.0 and Web 2.0, Web 2.0 technologies, and services in the education field.

4. The media elements including an introductory presentation on the infographic design and some video clips that demonstrate the use of Adobe Photoshop, Animaker, and Powtoon, and more instructions on the use of resources were made available to the participants through Blackboard.

5. All participants were required to watch the videos and other resources at home in advance. They get prepared for in-class activities by taking lesson notes. In the class, the teacher discussed the resources with them and answered their questions.

6. Groups completed their tasks and presented their work to the class and received feedback from the teacher and other groups.

7. The timeframe for the experiment was set. The application of the experiment took approximately eight weeks (February 5, 2018, through April 8, 2018).

8. The self-regulated learning scale (Magno, 2010) was administered at the end of the treatment.

9. After two weeks of the end of the treatment, a follow-up achievement test was applied to all the experimental groups (internal and external) to measure the learning retention.

10. The scores of the self-regulated learning scale and the achievement test were statistically analyzed using SPSS 22 . To test the research hypothesis, an independent sample t-test was utilized to measure the statistical differences between the average scores of the two experimental groups of the self-regulation learning scale and the achievement test. 


\section{FINDINGS AND DISCUSSION}

\section{Homogeneity between experimental groups}

An independent sample t-test was used to determine the homogeneity between the two experimental groups regarding achievement pretest scores. Table 1 shows the means and standard deviations (SDs) of the internal locus of control group $(\mathrm{M}=4.50, \mathrm{SD}=2.502$, $\mathrm{N}=30)$ and the external locus of control group $(\mathrm{M}=4.13, \mathrm{SD}=2.315, \mathrm{~N}=30)$.

Table 1

$\mathrm{t}$-Test for research groups on the achievement pretest

\begin{tabular}{lllllll}
\hline Group & $\mathrm{N}$ & Mean & $\mathrm{SD}$ & $\mathrm{Df}$ & $\mathrm{T}$ & \multirow{2}{*}{ Sig. } \\
\hline Internal locus of control & 30 & 4.50 & 2.502 & \multirow{2}{*}{58} & \multirow{2}{*}{0.589} & \multirow{2}{*}{0.558} \\
\hline External locus of control & 30 & 4.13 & 2.315 & & & \\
\hline
\end{tabular}

The t-test revealed no statistically significant differences between the two experimental groups before conducting the experiment $(t=0.589, p>0.05)$. Thus, the two groups are homogeneous.

\section{Self-regulated learning skills}

The independent samples t-test was used to identify significant differences between the two experimental groups in self-regulated learning skills. Table 2 shows the means and standard deviations of the internal locus of control group $(\mathrm{M}=183.80, \mathrm{SD}=12.882, \mathrm{~N}$ $=30)$ and external locus of control group $(\mathrm{M}=170.23, \mathrm{SD}=17.138, \mathrm{~N}=30)$.

Table 2

$\mathrm{t}$-Test for experimental groups on self-regulated learning skills scale scores

\begin{tabular}{lllllll}
\hline Group & $\mathrm{N}$ & Mean & S.D & Df & t & \multirow{2}{*}{ sig. } \\
\hline Internal locus of control & 30 & 183.80 & 12.882 & \multirow{2}{*}{58} & \multirow{2}{*}{3.466} & \multirow{2}{*}{0.001} \\
\hline External locus of control & 30 & 170.23 & 17.138 & & & \\
\hline
\end{tabular}

The results of the t-test analysis showed statistically significant differences $(0.05)$ between the average scores of the students of the two experimental groups. The selfregulated learning skills scale for the internal locus of control group scored $t=3.466$ and $\mathrm{p}<0.05$, with the highest mean value of 183.80 . Thus, the first hypothesis was rejected.

This finding may be explained due to the internally controlled students taking more responsibility for their learning, being more motivated, and depending less on the instructor's guidance. Like the self-regulated learning skills, these features illustrate that students engage positively in all learning activities and are more independent, autonomous, and self-driven learners. Students can understand their learning strengths and weaknesses. They also learn when to seek assistance and support. Contrary to the internally controlled students, the externally controlled students. That they are under the control of other and they have no control over their success (Hsia, 2016). They found online courses and materials to be difficult to use and not effective (Hsia et al., 2014). They do not have the ability for self-directed learning and continuously need help from the instructor to coach them and make decisions about their learning process. Therefore, it is reasonable that they may have lower self-regulated learning skills. 
The flipped learning environment offers learners self-paced learning opportunities, continuous interaction, involvement in learning activities, and instant feedback. This breaks the fear of participation and decreases dependency on instructors. In sum, the flipped learning model is a blended learning model that supports these skills and suits the nature of internally controlled students (Uzunboylu \& Karagozlu, 2015). This result agrees with the literature that flipped learning positively affects self-regulated learning skills (Alten et al., 2020; Jovanović et al., 2017; Ng, 2018; Peng, 2012; Sletten, 2015; Sun et al., 2017; Winne, 2013). This explains the flipped learning strategy's influence on improving and enhancing students' self-regulation skills of internally controlled students.

\section{Learning retention}

The independent samples t-test was used to identify the significance of the differences between the two experimental groups in learning retention. Table 3 shows the averages and standard deviations of the internal locus of control group $(\mathrm{M}=20.60, \mathrm{SD}=4.090$, $\mathrm{N}=30)$ and the external locus of control group $(\mathrm{M}=16.97, \mathrm{SD}=4.627, \mathrm{~N}=30)$.

Table 3

$\mathrm{t}$-Test for the experimental groups on learning retention test scores

\begin{tabular}{lllllll}
\hline Group & $\mathrm{N}$ & Mean & S.D & Df & t & sig. \\
\hline Internal locus of control & 30 & 20.60 & 4.090 & \multirow{2}{*}{58} & \multirow{2}{*}{3.222} & \multirow{2}{*}{0.002} \\
\hline External locus of control & 30 & 16.97 & 4.627 & & & \\
\hline
\end{tabular}

The results showed statistically significant differences $(0.05)$ between the mean scores of the students of the two experimental groups in the learning retention test $(t=3.222, p$ $<0.05)$ in favor of the internally controlled group. Thus, the second hypothesis was rejected.

Flipped learning highlights the role of students in their learning process. This active environment encourages students to be more learner-centered, affecting students' construction of knowledge and retention of information for as long as possible within their long-term memory. This comports with Estes et al. (2014), Hawks (2014), Kerr (2015), Mithun and Evans (2018), and Shatto et al. (2017), suggesting that flipped learning effectively improves students' learning retention.

As mentioned, the nature of students who are internally controlled comports agrees with the characteristics of the flipped learning environment. This helps internally controlled students retain information for a longer time than the externally controlled students. This result comports with most of the literature that confirms the outperformance of students with internal locus of control in terms of learning outcomes (Bajwa et al., 2016; Hsia, 2016; Hsia et al., 2014; Joo et al., 2013; Nakayama et al., 2015).

This result was not surprising. External controlled students would need the instructor to explain, guide, and help in doing all the learning tasks. They believe that they cannot control their learning or achievement and always search for a reason for their failures (Bajwa et al., 2016). Then a flipped classroom that is mainly a student-centered approach, where a teacher becomes a facilitator of the learning only, may not fit with 
such characteristics. Moreover, this result may be explained based on what proven in the literature that the external controlled students do not perceive e-learning environments as neither effective nor easy and do not like learning through them (Hsia, 2016). This, consequently, may negatively influence the external controlled students' achievement and learning retention.

\section{CONCLUSION}

This study investigated the influence of a flipped learning framework on improving selfregulated learning and learning retention of students with internal/external locus of control. The educational literature confirms the importance of studying students' characteristics to recognize methods related to how a person learns. This would provide teachers with knowledge on the design of appropriate teaching strategies related to students' learning styles. This may lead to more meaningful learning and increased interest in the subject matter. The literature reported flipped learning as a method to meet students' learning styles, support self-regulated learning skills, and improve learning outcomes like learning retention.

The primary findings of this study indicate that students who are internally locus controlled outperform those who are externally locus controlled in terms of selfregulated learning skills and learning retention. Flipped learning is compatible with students' characteristics of internal locus control, in which they are more self-directed, and more in charge of their learning. This, consequently, helps students to be more selfregulated and retain information for a longer time.

This study can be used as a preface for more investigations on the flipped learning environment using variables related to different stages of education. It is recommended to examine the influence of e-learning strategies (i.e., WebQuest, augmented reality, and project-based online learning) on enhancing self-regulated learning skills and learning retention. Studies on the impact of flipped learning on academic outcomes (i.e., achievement, performance, self-efficacy, and motivation) are also recommended. Likewise, learning styles (i.e., field-dependency independency, ambiguity tolerance, reflectivity, and impulsivity) in other e-learning environments should be examined with self-regulated learning skills and learning retention.

\section{ACKNOWLEDGEMENT}

The author acknowledges the Deanship of Scientific Research at King Faisal University for the financial support under Nasher Track (186082).

\section{REFERENCES}

Abeysekera, L., \& Dawson, P. (2015). Motivation and cognitive load in the flipped classroom: Definition, rationale and a call for research. Higher Education Research \& Development, 34(1), 1-14. https://doi.org/10.1080/07294360.2014.934336

Akçayır, G., \& Akçayır, M. (2018). The flipped classroom: A review of its advantages and challenges. Computers \& Education, 126, 334-345. https://doi.org/10.1016/j.compedu.2018.07.021 
Andriotis, N. (2017). Make your elearning stick: 8 tips \& techniques for learning retention. https://www.talentlms.com/blog/8-tips-techniques-learning-retention/

Bajwa, R. S., Batool, I., Azam, A., \& Ali, H. (2016). Impact of locus of control on life satisfaction among distance learning students. Journal of Educational Research, 19(1), 1027-9776.

https://www.thefreelibrary.com/Impact+of+Locus+of+Control+on+Life+Satisfaction+a mong+Distance...-a0480713116

Bandura, A. (1986). Social foundations of thought and action: A social cognitive theory. Prentice Hall.

Barak, M. (2009). Motivating self-regulated learning in technology education. International Journal of Technology and Design Education, 20(4), 381-401. https://doi.org/10.1007/s10798-009-9092-x

Baytiyeh, H. (2017). The flipped classroom model: When technology enhances professional skills. The International Journal of Information and Learning Technology, 34(1), 51-62. https://doi.org/10.1108/ijilt-07-2016-0025

Branch, R. M. (2009). Instructional design: The ADDIE approach. Springer Science + Business Media, LLC. https://doi.org/10.1007/978-0-387-09506-6

Broadbent, J. (2017). Comparing online and blended learner's self-regulated learning strategies and academic performance. The Internet and Higher Education, 33, 24-32. https://doi.org/10.1016/j.iheduc.2017.01.004

Broadbent, J., \& Poon, W. (2015). Self-regulated learning strategies \& academic achievement in online higher education learning environments: A systematic review. The Internet and Higher Education, 27, 1-13. https://doi.org/10.1016/j.iheduc.2015.04.007

Cab1, E. (2018). The impact of the flipped classroom model on students' academic achievement. International Review of Research in Open and Distributed Learning, 19(3), 202-212. https://doi.org/10.19173/irrodl.v19i3.3482

Chao, C. Y., Chen, Y. T., \& Chuang, K. Y. (2015). Exploring students' learning attitude and achievement in flipped learning supported computer aided design curriculum: A study in high school engineering education. Computer Applications in Engineering Education, 23, 514-526. https://doi.org/10.1002/cae.21622

Chen, Y. T., Liou, S., \& Chen, L. F. (2019). The relationships among gender, cognitive styles, learning strategies, and learning performance in the flipped classroom. International Journal of Human-Computer Interaction, 35(4-5), 395-403. https://doi.org/10.1080/10447318.2018.1543082

Chiang, H. H. (2016). A study of interactions among ambiguity tolerance, classroom work styles, and English proficiency. English Language Teaching, 9(6), 61-75. https://doi.org/10.5539/elt.v9n6p61

Chiang, H. H. (2016). A study of interactions among ambiguity tolerance, classroom work styles, and English proficiency. English Language Teaching, 9(6), 61--75. https://doi.org/10.5539/elt.v9n6p61 
Cox, J. (2012). Information systems user security: A structured model of the knowledgedoing gap. Computers in Human Behavior, 28(5), 1849-1858. https://doi.org/10.1016/j.chb.2012.05.003

Elakovich, D. M. (2018). Does a student's use of self-regulation change in the flipped classroom? [Doctoral dissertation]. Montana State University-Bozeman, College of Education, Health \& Human Development. https://scholarworks.montana.edu/xmlui/bitstream/handle/1/14547/ElakovichD0518.pdf ?sequence $=1 \&$ is Allowed $=\mathrm{y}$

Estes. M. D., Ingram, R., \& Liu, J. C. (2014). A review of flipped classroom research, practice, and technologies. International HETL Review, Volume 4. https://www.hetl.org/feature-articles/a-review-of-flipped-classroom-research-practiceand-technologies

Garcia, R., Falkner, K., \& Vivian, R. (2018). Systematic literature review: Selfregulated learning strategies using e-learning tools for computer science. Computers \& Education, 123, 150-163. https://doi.org/10.1016/j.compedu.2018.05.006

Gökçearslan, Ş., \& Alper, A. (2015). The effect of locus of control on learners'sense of community and academic success in the context of online learning communities. The Internet and Higher Education, 27, 64-73. https://doi.org/10.1016/j.iheduc.2015.06.003

Hao, Y. (2016). Exploring undergraduates' perspectives and flipped learning readiness in their flipped classrooms. Computers in Human Behavior, 59, 82-92. https://doi.org/10.1016/j.chb.2016.01.032

Hawks, S. J. (2014). The flipped classroom: Now or never? Journal of the American Association of Nurse Anesthetists, 82(4), 264-269. https://pdfs.semanticscholar.org/1ccc/20a540c78cf9f89c440b29958f550b7fdf4b.pdf?_g $\mathrm{a}=2.147721207 .1944595580 .1592113862-1457079528.1551776596$

Hsia, J. W. (2016). The effects of locus of control on university students' mobile learning adoption. Journal of Computing in Higher Education, 28(1), 1-17. https://doi.org/10.1007/s12528-015-9103-8

Hsia, J.-W., Chang, C.-C., \& Tseng, A.-H. (2014). Effects of individuals' locus of control and computer self-efficacy on their e-learning acceptance in high-tech companies. Behaviour \& Information Technology, 33(1), 51-64. https://doi.org/10.1080/0144929x.2012.702284

Ismaeel, D. A., \& Al Mulhim, E. N. (2019). Influence of augmented reality on the achievement and attitudes of ambiguity tolerant/intolerant students. International Education Studies, 12(3), 59-70. https://doi.org/10.5539/ies.v12n3p59

Joo, Y. J., Joung, S., \& Sim, W. J. (2011). Structural relationships among internal locus of control, institutional support, flow, and learner persistence in cyber universities. Computers in Human Behavior, 27, 714-722. https://doi.org/10.1016/j.chb.2010.09.007

Joo, Y. J., Lim, K. Y., \& Kim, J. (2013). Locus of control, self-efficacy, and task value as predictors of learning outcome in an online university context. Computers \& Education, 62, 149-158. https://doi.org/10.1016/j.compedu.2012.10.027 
Jovanović, J., Gašević, D., Dawson, S., Pardo, A., \& Mirriahi, N. (2017). Learning analytics to unveil learning strategies in a flipped classroom. The Internet and Higher Education, 33(4), 74-85. https://doi.org/10.1016/j.iheduc.2017.02.001

Kang, N. (2015). The comparison between regular and flipped classrooms for EFL Korean adult learners. Multimedia-Assisted Language Learning, 18(3), 41-72. https://doi.org/10.15702/mall.2015.18.3.41

Kelly, B. J. (2012). The impact of sense of community, personality preference, and locus of control on attrition rates in web-based learning. [Doctoral dissertation]. Walden University. https://www.learntechlib.org/p/122046/

Kerr, B. (2015). The flipped classroom in engineering education: A survey of the research. In 2015 International Conference on Interactive Collaborative Learning (ICL) (pp. 815-818). IEEE. https://doi.org/10.1109/icl.2015.7318133

Lai, C. L., \& Hwang, G. J. (2016). A self-regulated flipped classroom approach to improving students' learning performance in a mathematics course. Computers \& Education, 100, 126-140. https://doi.org/10.1016/j.compedu.2016.05.006

Littlejohn, A., Hood, N., Milligan, C., \& Mustain, P. (2016). Learning in MOOCs: Motivations and self-regulated learning in MOOCs. The Internet and Higher Education, 29, 40-48. https://doi.org/10.1016/j.iheduc.2015.12.003

Magno, C. (2010). Assessing academic self-regulated learning among Filipino college students: The factor structure and item fit. The International Journal of Educational and Psychological Assessment, 5(1), 61-76. https://ssrn.com/abstract=2287208

Milman, N. B. (2014). The flipped classroom strategy: What is it and how can it best be used? Distance Learning, 11(4), 9-11. https://www.academia.edu/22761397/The_Flipped_Classroom_Strategy_What_Is_It_an d_How_Can_It_Best_Be_Used

Mithun, S. \& Evans, N. (2018). Impact of the flipped classroom on students learning and retention in teaching programming. In 2018 ASEE Annual Conference \& Exposition, June 24-27, Saltlake city, USA. https://www.asee.org/public/conferences/106/papers/21586/download

Nakayama, M., Leh, A., \& Santiago, R. (2015, July). Relationships of student experience and student characteristics in a graduate-level flipped classroom. In Proceedings of the $2 n d$ European Conference on Social Media 2015: ECSM 2015 (p. 348).

$\mathrm{Ng}$, E. M. (2018). Integrating self-regulation principles with flipped classroom pedagogy for first year university students. Computers \& Education, 126, 65-74. https://doi.org/10.1016/j.compedu.2018.07.002

O'Flaherty, J., \& Phillips, C. (2015). The use of flipped classrooms in higher education: A scoping review. The Internet and Higher Education, 25, 85-95. https://doi.org/10.1016/j.iheduc.2015.02.002

Onyekuru, B. U. (2015). Field dependence-field independence cognitive style, gender, career choice and academic achievement of secondary school students in emohua local 
government area of rivers state. Journal of Education and Practice, 6(10), 76-85. https://www.iiste.org/Journals/index.php/JEP/article/view/21440/22147

Peng, C. (2012). Self-regulated learning behavior of college students of science and their academic achievement. Physics Procedia,33, 1446-1450. https://doi.org/10.1016/j.phpro.2012.05.236

Rotter, J. B. (1954). Social learning and clinical psychology. Prentice-Hall. https://doi.org/10.1037/10788-000

Rotter, J. B. (1966). Generalized expectancies for internal versus external control of reinforcement. Psychological monographs: General and Applied,80(1), 1-28. https://doi.org/10.1037/h0092976

Schraw, G., Kauffman, D., \& Lehman, S. (2002). Self-regulated learning theory. In The encyclopedia of cognitive science, L. Nadel, Ed. Nature Publishing Company, London, 1063-1073.

Serdyukov, P., \& Hill, R. (2013). Flying with clipped wings: Are students independent in online college classes? Journal of Research in Innovative Teaching, 6(1), 54-67. https://www.nu.edu/wp-content/uploads/2018/11/journal-of-research-in-innovativeteaching-volume-6.pdf\#page $=59$

Severino, S., Aiello, F., Cascio, M., Ficarra, L., \& Messina, R. (2011). Distance education: The role of self-efficacy and locus of control in lifelong learning. Procedia$\begin{array}{llll}\text { Social and Behavioral } & \text { Sciences, } & \text { 28(2), } & \text { 705-717. }\end{array}$ https://doi.org/10.1016/j.sbspro.2011.11.132

Shahsavar, Z., \& Hoon, T. B. (2011). Does cognitive style affect bloggers' attitude in an online learning environment? GEMA Online ${ }^{\circledR}$ Journal of Language Studies, 11(1), 159171. http://ejournals.ukm.my/gema/article/download/73/67

Shatto, B., L'Ecuyer, K., \& Quinn, J. (2017). Retention of content utilizing a flipped classroom approach. Nursing education perspectives, 38(4), 206-208. https://doi.org/10.1097/01.nep.0000000000000138

Shyr, W. J., \& Chen, C. H. (2018). Designing a technology-enhanced flipped learning system to facilitate students' self-regulation and performance. Journal of Computer Assisted Learning, 34(1), 53-62. https://doi.org/10.1111/jcal.12213

Sletten, S. R. (2017). Investigating flipped learning: Student self-regulated learning, perceptions, and achievement in an introductory biology course. Journal of Science Education and Technology, 26(3), 347-358. https://doi.org/10.1007/s10956-016-9683-8

Sletten, S.R. (2015). Investigating Self-Regulated Learning Strategies in the Flipped Classroom. In D. Rutledge \& D. Slykhuis (Eds.), Proceedings of SITE 2015--Society for Information Technology \& Teacher Education International Conference (pp. 497-501). Las Vegas, NV, United States: Association for the Advancement of Computing in Education (AACE). https://www.learntechlib.org/primary/p/150041/

Song, Y., \& Kapur, M. (2017). How to flip the classroom - "Productive failure or traditional flipped classroom" pedagogical design? Educational Technology \& Society, 20(1), 292-305. https://www.jstor.org/stable/pdf/jeductechsoci.20.1.292.pdf?seq=1 
Sun, J. C. Y., Wu, Y. T., \& Lee, W. I. (2017). The effect of the flipped classroom approach to OpenCourseWare instruction on students' self-regulation. British Journal of Educational Technology, 48(3), 713-729. https://doi.org/10.1111/bjet.12444

Sun, Z., Xie, K., \& Anderman, L. H. (2018). The role of self-regulated learning in student's success in flipped undergraduate math courses. The Internet and Higher Education, 36, 41-53. https://doi.org/10.1016/j.iheduc.2017.09.003

Tayebinik, M., \& Puteh, M. (2013). The role of ambiguity tolerance in participation in online EFL courses. British Journal of Educational Technology, 44(6), E207-E208. https://doi.org/10.1111/bjet.12087

Tune, J. D., Sturek, M., \& Basile, D. P. (2013). Flipped classroom model improves graduate student performance in cardiovascular, respiratory, and renal physiology. Advances in Physiology Education, 37(4), 316-320. https://doi.org/10.1152/advan.00091.2013

Uzunboylu, H., \& Karagozlu, D. (2015). Flipped classroom: A review of recent literature. World Journal on Educational Technology, 7(2), 142-147. https://doi.org/10.18844/wjet.v7i2.46

van Alten, D. C., Phielix, C., Janssen, J., \& Kester, L. (2020). Effects of self-regulated learning prompts in a flipped history classroom. Computers in Human Behavior, 108(106318), 1-13. https://doi.org/10.1016/j.chb.2020.106318

Wang, C. H., Shannon, D., \& Ross, M. (2013). Students' characteristics, self-regulated learning, technology self-efficacy, and course outcomes in online learning. Distance Education, 34(3), 302-323. https://doi.org/10.1080/01587919.2013.835779

Wang, H. C. (2014). Seeing the forest and the trees: pictorial complexity, field dependence/independence, and English listening comprehension. English Teaching \& Learning, 38(4), 125-151. https://doi.org/10.6330/ETL.2014.38.4.05

Wang, K., \& Zhu, C. (2019). MOOC-based flipped learning in higher education: students' participation, experience and learning performance. International Journal of Educational Technology in Higher Education, 16(1), 16-33. https://doi.org/10.1186/s41239-019-0163-0

Wiginton, B. L. (2013). Flipped instruction: An investigation into the effect of learning environment on student self-efficacy, learning style, and academic achievement in an algebra I classroom. $\mathrm{PhD}$ dissertation, the University of Alabama. http://libcontent.lib.ua.edu/content/u0015/0000001/0001416/u0015_0000001_0001416.pdf

Winne, P. H. (2013). Learning strategies, study skills, and self-regulated learning in postsecondary education. In M. B. Paulsen (Ed.), Higher education: Handbook of theory and research (volume 28, pp. 377-403). Springer. https://doi.org/10.1007/97894-007-5836-0_8

Zimmerman, B. (1989). A social cognitive view of self-regulated academic learning. Journal of Educational Psychology, 81(3), 329-339. https://doi.org/10.1037/00220663.81.3.329 